\title{
Proses Penambangan Pasir Pantai dan Dampaknya Terhadap Lingkungan Di Kecamatan Ambalawi Kabupaten Bima
}

\author{
Syafruddin ${ }^{1}$, Ihsan ${ }^{2}$ \\ ${ }^{1,2}$ STKIP Taman Siswa Bima \\ syafruddin83@gmail.com
}

\begin{abstract}
ABSTRAK
Bukti Ketergantungan bangsa Indonesia kepada alam dapat dilihat dari pemanfaatan sumber daya alam yang besar-besaran tanpa melihat kelanjutan fungsinya. sentralisasi pemerintahan, kegiatan exploitasi terhadap sumber daya alam yang tidak berwawasan lingkungan masih terbatas pada pemanfaatan wilayah-wilayah yang strategis saja, namun dewasa ini setiap daerah saling belomba-lomba mengeksploitasi dan memanfaatkan kekayaan alam masing-masing. Penambangan pasir di pantai memang dianggap memberikan kontribusi yang cukup besar bagi masyarakat di Kecamatan Ambalawi Kabupaten Bima, hal ini dapat terlihat dari begitu banyaknya aktivitas penggalian pasir di pantai yang dilakukan oleh masyarakat di Kecamatan Ambalawi Kabupaten Bima. Kegiatan penambangan pasir pantai sering dikonotasikan sebagai salah satu kegiatan yang merusak lingkungan, hal itu dapat terjadi apabila kegiatan penambangan tidak terkendali pasti akan menimbulkan dampak lingkungan, baik bersifat positif maupun bersifat negatif. Meskipun demikian besarnya permintaan pasar terhadap pasir turut mendorong berkembangnya kegiatan ini dengan pesat. Akibatnya, munculah berbagai masalah terhadap lingkungan. Rumusan masalah dalam penelitia ini adalah sebagai berikut: 1) Bagaimanakah proses penambangan pasir pantai yang dilakukan masyarakat di Kecamatan Ambalawi Kabupaten Bima? 2) Bagaimanakah dampak positif maupun dampak negatif yang ditimbulkan dari adanya eksploitasi pasir pantai di Kecamatan Ambalawi Kabupaten Bima?. Tujuan penelitian ini adalah sebagai berikut: 1) Untuk mengetahui proses penambangan pasir pantai yang dilakukan masyarakat di Kecamatan Ambalawi Kabupaten Bima. 2)Untuk mengetahui dampak positif maupun dampak negatif yang ditimbulkan dari adanya eksploitasi pasir pantai di Kecamatan Amba Lawi Kabupaten Bima. Kesimpulan Kegiatan eksploitasi pasir pantai yang berlebihan akan berdampak pada rusaknya kel estarian sumber daya alam dan rusaknya fungsi lingkungan pantai. Eksploitasi pasir pantai yang terus mengalami peningkatan. Kerusakan tersebut disebabkan oleh kegiatan penambangan yang dilakukan secara kelompok terus-menerus dan dilakukan secara ilegal atau tidak berizin. Kerusakan pantai karena eksploitasi yang terus terjadi di sepanjang pantai di kecamatan ambalawi. Dengan bertambahnya Jumlah penduduk yang terus meningkat dan ketersediaan lahan pertanian dan ketrsedian lapangan kerja yang sedikit menyebabkan masyarakat banyak yang alih profesi menjadi penambang pasir pantai. Hal ini yang terjadi pada masyakat yang tinggal di sepanjang pesisir pantai di Kecamatan ambalawi kabupaten Bima. Ada berbagai alasan yang menyebabkan kegiatan eksploitasi pasir pantai terus dilakukan di Kecamatan ambalawi kabupaten Bima antara lain: 1) Pengetahuan masyarakat tentang dampak kerusakan lingkungan pantai. Banyak masyarakat yang tidak mengetahui dampak jangka panjang yang di timbulkan oleh kegiatan eksploitasi pasir pantai. Masyarakat hanya berpikir untuk memenuhi kebutuhan ekonomi. Masyarakat menganggap bahwa lingkungan itu milik umum, sehingga masyarakat berhak mengeksploitasi sumber daya alam tersbut. 2)Pengetahuan masyarakat tentang illegal. Bagi masyarakat ilegal diartikan sebagai segala sesuatu yang sesuai dengan peraturan perundang-undangan yang di perbolehkan. Masyarakat yang melakukan penambangan akan dianggap legal sehingga masyarakat melakukan kegiatan penambangan tersebut. Dalam hal ini Peran pemerintah daerah dalam menyikapi aktivitas penambangan pasir pantai secara illegals sangat diperlukan Peraturan.
\end{abstract}

Kata kunci: Proses penambang pasir pantai. 


\section{PENDAHULUAN}

Bukti Ketergantungan bangsa Indonesia kepada alam dapat dilihat dari pemanfaatan sumber daya alam yang besar-besaran tanpa melihat kelanjutan fungsinya. sentralisasi pemerintahan, kegiatan exploitasi terhadap sumber daya alam yang tidak berwawasan lingkungan masih terbatas pada pemanfaatan wilayah-wilayah yang strategis saja, namun dewasa ini setiap daerah saling belomba-lomba mengeksploitasi dan memanfaatkan kekayaan alam masing-masing.

Penambangan pasir di pantai memang dianggap memberikan kontribusi yang cukup besar bagi masyarakat di Kecamatan Ambalawi Kabupaten Bima, hal ini dapat terlihat dari begitu banyaknya aktivitas penggalian pasir di pantai yang dilakukan oleh masyarakat di Kecamatan Ambalawi Kabupaten Bima. Kegiatan penambangan pasir pantai sering dikonotasikan sebagai salah satu kegiatan yang merusak lingkungan, hal itu dapat terjadi apabila kegiatan penambangan tidak terkendali pasti akan menimbulkan dampak lingkungan, baik bersifat positif maupun bersifat negatif.

Berdasarkan rumusan masalah di atas, maka tujuan penelitian ini adalah sebagai berikut: 1) Untuk mengetahui proses penambangan pasir pantai yang dilakukan masyarakat di Kecamatan Ambalawi Kabupaten Bima. 2) Untuk mengetahui dampak positif maupun dampak negatif yang ditimbulkan dari adanya eksploitasi pasir pantai di Kecamatan Amba Lawi Kabupaten Bima.

Penelitian yang dilakukan diasumsikan akan membantu pelestarian lingkungan dan Untuk menambah wawasan dan konsep keilmuan terhadap lingkungan hidup di Kecamatan Ambalawi Kabupaten Bima.

\section{Proses Penambagan Pasir}

Proses pemabangan pasir di kecamatan ambalawi kabuapten bima yaitu dilakukan dengan cara tradisional. Penambagan pasir yang dilakukan hanya dengan menggunakan alat alat seder hana seperti cangkul, pengeruk pasir, apabila penggalian dengan jumlah pasir yang cukup besar, biasanya kendaraan pengakut pasir ini langsung di amsukan ke lokasi penambangan, guna mempermuda pengankutan

\section{Tinjauan tentang Eksploitasi}

Eksploitasi menurut kamus besar bahasa Indonesia (KBBI) merupakan pengusahaan, pendayagunaan atau pemanfaatan sesuatau untuk keuntungan sendiri. Kegiatan Eksploitasi ini dapat menciptakan kerusakan. Penambangan dalam skala besar dapat mengakibatkan kerusakan lingkungan. Eksploitasi sering disampingkan dengan kegiatan pertambangan.

Eksploitasi adalah usaha penambangan dengan maksud untuk menghasilkan bahan galian dan memanfaatkannya. Kegiatan ini dapat dibedakan berdasarkan sifat bahan galiannya yaitu, galian padat dan bahan galian cair serta gas. Eksploitasi merupakan pengambilan sumberdaya alam untuk dipakai atau dipergunakan atau dimanfaatkan dalam berbagai keperluan manusia dalam memenuhi kebutuhannya (Nurkartika, 2001).

\section{Tinjauan Tentang Kegiatan Penambang}

Tanah merupakan salah satu faktor yang penting bagi kehidupan manusia. Akan tetapi sangat disayangkan bahwa pada umunya setelah manusia berhasil menguasai sebidang atau seluas tanah, mereka mengabaikan fungsi tanah, bahkan merusak dan selanjutnya dan menelantarkan tanah itu sendiri (Karta sapoetra $\mathrm{dkk}, 2005)$

Usaha penambangan merupakan usaha melakukan eksplorasi, eksploitasi, produksi dan penjual. Menurut Rahmi (1995), penggolongan bahan-bahan galian adalah sebagai berikut: 1) Golongan a, merupakan bahan galian strategis, yaitu strategis untuk perekonomian Negara serta pertahan dan kemanan Negara. 2) Golongan b, merupakan bahan galian vital, yaitu menjamin hajat hidup orang banyak, contahnya besi, tembaga, emas, perak dan lain-lain. 3) Golongan c, bukan merupakan bahan galian strategis ataupun vital, karena sifatnya tidak langsung memerlukan pasaran internasional. Contohnya marmer, batu kapur, tanah liat, pasir, yang sepanjang tidak mengandung unsur mineral.

Menurut Undang-Undang Nomor 11 tahun 1967 tentang ketentuan-ketenuan pokok pertambangan menyebutkan bahwa 
pertambangan rakyat adalah suatu usaha pertambangan bahan-bahan galian dari semua golongan a, b dan c yang dilakukan oleh rakyat secara kecil-kecilan atau gotong royong dengan alat-alat sederhana pencarian sendiri. (As'ad, 2005). Pertambagan rakyat di lakukan oleh rakyat, artainya dilakukan oleh masyarakat yang berdomisili di area pertambangan secara kcil kecilan atau gotong royong dengan alat-alat sederhana. Tujuan mereka adalah untuk meningkatkan kehidupan sehari-hari. Dilaksanakan secara sederhana dan dengan alat sederhana, jadi tidak menggunakan teknologi canggih, sebagaimana halnya dengan perusahaan pertambangan yang mempunyai modal besar dan memakai teknologi canggih. Dari uraian diatas, dapat dikemukakan unsur-unsur pertambagan rakyat, yaitu: 1) Usaha pertambangan. 2) Bahan galain meliputi bahan galian strategis, vital dan galian c. 3) Dilakukan oleh rakyat. 4) Domisili di area tambagan rakyat. 5) Untuk kehidupan sehari-hari. 6) Diusahakan dengan cara sederhana.

\section{METODE PENELITIAN}

\section{Tahapan Penelitian}

Tahap Persiapan: a) Menentukan masalah yang akan dikaji dan mencermati fenomena yang terjadi pada masyarakat di kecamatan Ambalawi kabupaten Bima. b)Mendalami literatur untuk menentukan teori yang dianggap tepat dalam mengkaji permasalahan yang diangkat. c)Merancang proposal yang berisi permasalahan serta teori yang menjadi dasar sudut pandang hingga penganalisan. d) Membuat instrumen pertanyaan untuk mememperoleh informasi sesuai rumusan masalah yang diangkat.

Tahap Pelaksanaan: a) Melaksanakan penelitian pada objek kajian yang menekankan pencarian informasi pada proses penambang pasir pantai. b) Mengumpulkan informasi dengan wawancara.

Tahap Akhir: a) Menelaah data sesuai teori secara deskriptif. b) Membuat kesimpulan dan saran berdasarkan temuan penelitian.c) Membuat kesimpulan dan saran berdasarkan temuan penelitian.

\section{Setting Penelitian}

Lokasi penelitian akan dilaksanakan di Kecamatan Ambalawi Kabupaten Bima. Informan (subjek penelitian) yang dibutuhkan dalam penelitian adalah masyarakat penambang pasir pantai. Instrumen dalam penelitian ini adalah wawancara (daftar pertanyaan), dan caat untuk memperoleh informasi yang dibutuhkan.

\section{Metode dan Rancangan Penelitian}

Penelitian ini menggunakan metode kualitatif bersifat deskriptif bertujuan memberikan gambaran yang jelas, objektif, sistematis, secara cermat mengenai fakta-fakta yang akan diperoleh dari objek yang ditelaah.

Untuk memahami tentang penggunaan metode tersebut dalam penelitian ini akan dikemukakan rancangan penelitian sebagai berikut.

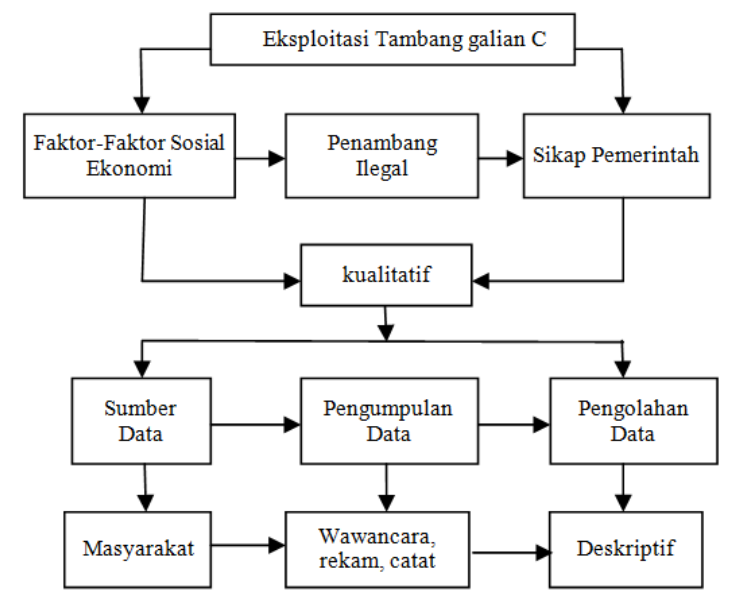

\section{Teknik Pengumpulan Data}

Mempertimbangkan penelitian akan dilakukan di lapangan untuk memperoleh informasi tentang proses penambang pasir pantai. Adapun teknik pengumpulan data yang digunakan dalam penelitian berupa wawancara, dan catat. Penggunaan wawancara untuk menggali informasi kepada informan terkait proses penambang pasir pantai yang dilakukan oleh masyarakat kecamatan Ambalawi Kabupaten Bima bisa dijadikan materi pelajaran di Sekolah Dasar. Wawancara untuk memperoleh keterangan yang disampaikan informan yang telah diwawancarai dapat membantu memudahkan peneliti mendeskripsikan informasi lisan menjadi tulisan tuntuk menunjang pengumpulan informasi saat peneliti melakukan wawancara, proses 
mendeskripsikan sumber pustaka dengan mengutip informasi dianggap sangat penting.

\section{Teknik Penganalisisan Data}

Proses pengumpulan data telah dirampungkan, maka ditindak lanjuti dengan proses pengolahan data. Adapun pendekatan yang digunakan bersifat deskriptif dalam menyampaikan berbagai informasi yang diperlukan. Proses yang dimaksud melalui uraian kata-kata dalam menjawab permasalahan dan solusi pada objek yang akan diteliti. Langkah pengolahan data secara deskriptif meliputi rangkaian dan mentranskripsi per kata dalam proses wawancara sehingga bisa dikelompokkan menjadi kata, maupun kalimat. Memperoleh informasi penunjangnya dan selanjutnya uraikan dengan model pembelajaran berwawasan lingkungan di Sekolah Dasar. Penyajian hasil pengolahan data secara deskriptif dilakukan secara formal dan informal. Formal direalisasikan dalam deskripsi bagan, tabel, dan gambar sedangkan informal disajikan dalam uraian terperinci kata per kata.Secara khusus penggunaan informal dalam penyajian penelitian memungkinkan menghasilkan penjelasan suatu permasalahan lebih rinci sehingga dapat memberikan tingkat keterbacaan yang tinggi terhadap hasil penelitian yang dilakukan.

\section{HASIL DAN PEMBAHASAN}

Masyarakat di kecamatan ambalawi yang tingaal di daerah pesisir pantai merupakan sebagian besar sebagai petani dan ada juga sebgai nelayan. Pada bulan mei masyarakat petani yang ada di daerah pesisir pantai banyak yang berali profesi sebagai penambang Pasir pantai karena merupakan bahan material yang mudah di dapat dan banyak dibutuhukan dalam berbagai pembangunan sarana fisik. Pembangunan yang banyak membutuhkan pasir sehingga masyarakat banyak melakuan sebagai penambangan pasir pantai. penambangan pasir dilakukan secara sederhana dengan alat sederhana. Pasir pantai bagi sebagian masyarakat pesisi merupakan salah satu sumber ekonomi untuk memenuhi kebutuhan sehari-hari. Aktivitas penambangan dilakukan di sepanjang pesisir pantai yang ada di kecamatan ambalawi.

\section{PEMBAHASAN}

Faktor sosial ekonomi: a) Tingkat Pendidikan. Dalam mendukung kehidupan sosial, pendidikan merupakan salah satu faktor yang sangat penting untuk menjamin kualitas sumber daya manusia (SDM). Tingkat pendidikan akan mempengaruhi pola pikir, dan interaksi sosial seseorang sebagai anggota masyarakat dalam melakukan aktivitas untuk menunjang kebutuhan hidupnya. Pendidikan secara langsung memberi kontribusi terhadap keterampilan dan kelangsungan hidup pada seseorang. Sementara kualitas sumber daya manusia Indonesia relative masih rendah.

Tingkat pendidikan masyarakat bervariasi, terdapat tamatan berbagai jenjang pendidikan, yaitu tamatan SD bahkan ada tidak sempat menamatkan di bangku SD, tamatan SLTP, tamatan SLTA dan tamatan perguruan tinggi yang hanya berjumlah sangat kecil. Pada umumnya masyarakat pesisir pantai hanya sekolah pada jenjang pendidikan sekolah dasar dan SLTP selebihnya mereka lebih memilih bekerja untuk menghasilkan uang atau pergi merantau. Seiring perkembangan jaman masyarakat pesisir pantai Sadar akan pentingnya pendidikan, terbukti sudah banyak melanjutkan pendidikan sampai perguruan tinggi bahkan sudah ada yang menggelar sarjana dari berbagai jurusan. b) Mata Pencahrian. Potensi ekonomi yang dikembangkan oleh masyarakat pesisir pantai di Ambalawi untuk penunjang mata pencaharian umumnya berkaitan dengan sektor petani, nelayan dan penambang pasir. Disamping itu juga ada sebagian penduduk yang berprofesi sebagai pegawai negri sipil, pedagang, dan sebagainya.

Sumber mata pencaharian masyarakat pesisir pantai di kecamatan ambalawi terpusat pada petani, nselayan, penambang pasir, yang mana hampir semua masyarakat pesisir pantai ini menggantungkan hidupnya pada hasil petani nelayan, penambang pasir. Dilihat dari segi partisipasi anggota keluarga dalam bekerja, setiap anggota keluarga baik suami atau istri bahkan anak terlibat dalam mencari nafkah untuk mencukupi kebutuhan hidup. c) Aktivitas 
Sosial. Selain melakukan aktivitas ekonomi, masyarakat pesisir pantai juga melakukan kegiatan-kegiatan dalam bentuk gotong royong dan sebagainya. Kegiatan yang sering Organisasi sosial tumbuh dengan baik seperti PKK, Karang Taruna, Kelompok penambang pasir, Organisasi Kependudukan lainnya. Kegiatan sosial lain yang biasa dilaksanakan seperti acara tujuh belas Agustus, dan pertandingan bola voli, sepakbola antar desa. Hal ini dimaksudkan untuk menjalin keakraban.

\section{Proses penambangan pasir pantai}

Proses penambangan pasir yang dilakukan di Kecamatan Ambalawi Kabupaten Bima yaitu dilakukan dengan cara tradisional. Penambangan pasir yang dilakukan hanya dengan menggunakan alat-alat yang sederhana/tradisional seperti: cangkul, sekop pasir, dan kendaraan pengangkut pasir ini langsung dimasukan ke lokasi penambangan yang dekat dengan jalan, guna mempermudah proses pengakutan.

\section{Dampak terhadap lingkunngan.}

Berdasarkan hasil penelitian menunjukkan aktivitas penambangan pasir pantai memiliki dampak yang cukup besar terhadap perubahan lingkungan fisik. Dengan adanya aktivitas penambangan pasir pantai secara tradisional/sederhana di Kecamatan Ambalawi ditemukan adanya dampak positif dan negatif, dampak positif diantaranya menambah penghasilan atau pendapatan masyarakat dan tersedianya lapangan kerja sedangak dapak negatifnya terdiri dari meningkatnya kerusakan pada tanggul dan terjadi abrasi, kerusakan jalan di sepanjang pantai.

\section{Sikap pemerintah}

Sikap pemerintah terhadap penambang pasir pantai seakan membiarkan karena pemerintah tidak memberikan himbauan atau mensosialisasikan terhdapa masyarakat mengenai dampak yang akan di timbulkan dari penambang pasir pantai tersebut.

\section{KESIMPULAN}

Kegiatan eksploitasi pasir pantai yang berlebihan akan berdampak pada rusaknya kelestarian sumber daya alam dan rusaknya fungsi lingkungan pantai. Eksploitasi pasir pantai yang terus mengalami peningkatan. Kerusakan tersebut disebabkan oleh kegiatan penambangan yang dilakukan secara kelompok terus-menerus dan dilakukan secara ilegal atau tidak berizin. Kerusakan pantai karena eksploitasi yang terus terjadi di sepanjang pantai di kecamatan ambalawi.

Dengan bertambahnya Jumlah penduduk yang terus meningkat dan ketersediaan lahan pertanian dan ketrsedian lapangan kerja yang sedikit menyebabkan masyarakat banyak yang alih profesi menjadi penambang pasir pantai. Hal ini yang terjadi pada masyakat yang tinggal di sepanjang pesisir pantai di Kecamatan ambalawi kabupaten Bima. Ada berbagai alasan yang menyebabkan kegiatan eksploitasi pasir pantai terus dilakukan di Kecamatan ambalawi kabupaten Bima antara lain: 1) Pengetahuan masyarakat tentang dampak kerusakan lingkungan pantai. Banyak masyarakat yang tidak mengetahui dampak jangka panjang yang di timbulkan oleh kegiatan eksploitasi pasir pantai. Masyarakat hanya berpikir untuk memenuhi kebutuhan ekonomi. Masyarakat menganggap bahwa lingkungan itu milik umum, sehingga masyarakat berhak mengeksploitasi sumber daya alam tersbut. 2) Pengetahuan masyarakat tentang illegal. Bagi masyarakat ilegal diartikan sebagai segala sesuatu yang sesuai dengan peraturan perundang-undangan yang di perbolehkan. Masyarakat yang melakukan penambangan akan dianggap legal sehingga masyarakat melakukan kegiatan penambangan tersebut.

Dalam hal ini Peran pemerintah daerah dalam menyikapi aktivitas penambangan pasir pantai secara illegals sangat diperlukan Peraturan Daerah (Perda), teguran lisan, dan sosialisasi. Perda penambangan yang dikeluarkan pemerintah dalam bentuk Peraturan dan Teguran lisan yang diberikan berupa peringatan.

\section{DAFTAR PUSTAKA}

Akademi Teknik Pertambangan Nasional, Banjarbaru.

As'ad, 2005. Tesis: Pengelolaan Lingkungan pada Penambang Rakyat (Studi Kasus 
Penanbang Intan Rakyat di Kecamatan

Cempaka Kota Banjarbaru Provinsi

Kalimantan selatan).

Kartasapoetra, dkk, 2005, Teknologi Konservasi

Tanah dan air, cetak ke V, Rineka Cipta:

Jakarta

Nurkartika, 2001. Intisari Biologi. PT Aksarindo

Prima Cipta: Jakarta

Rahmi, F., 1995. Sistem dan Alat Tambang, 